\title{
THE WATER LEVEL INFLUENCE ON BIOMASS OF Echinochloa polystachya (POACEAE) IN THE JURUMIRIM RESERVOIR (SÃO PAULO, BRAZIL)
}

\author{
POMPÊO, M. L. M., HENRY, R. and MOSCHINI-CARLOS, V. \\ Departamento de Zoologia, Instituto de Biociências, Unesp, C.P. 510, CEP 18618-000, Botucatu, SP, Brazil \\ Correspondence to: Raoul Henry, Departamento de Zoologia, Instituto de Biociências, Unesp, C.P. 510, \\ CEP 18618-000, Botucatu, SP, Brazil \\ Received June 28, 1999 - Accepted March 21, 2000 - Distributed February 28, 2001
}

(With 5 figures)

\begin{abstract}
In the Paranapanema River mouth, Jurumirim Reservoir $\left(23^{\circ} 27^{\prime}-23^{\circ} 29^{\prime} \mathrm{S}\right.$ and $48^{\circ} 39^{\prime}-48^{\circ} 36^{\prime} \mathrm{W}$, SP, Brazil), the biomass of E. polystachya was monthly determined with eight quadrats of $0.25 \mathrm{~m}^{2}$ from August 1993 to July 1994. The seasonal variation in biomass was unimodal, with greater biomass from November 1993 to April 1994. The average biomass was 1,933.7 $\pm 479.5 \mathrm{gDW} . \mathrm{m}^{-2}$, with a variation along the year from $1,149.0$ to $2,755.9 \mathrm{gDW} . \mathrm{m}^{-2}$. The annual variation of aerial green biomass, aerial and aquatic detritus suggest that the main growth period of E. polystachya was from December 1993 to May 1994, with peak between February to March 1994. The data indicate that this macrophyte is adapted to water level variation.
\end{abstract}

Key words: macrophyte, Echinochloa, biomass, water level variation, reservoir, Poaceae.

\section{RESUMO}

Influência do nível da água na biomassa de Echinochloa polystachya (Poaceae) no Reservatório de Jurumirim (São Paulo, Brasil)

Na zona de desembocadura do Rio Paranapanema, Reservatório de Jurumirim (2327'-23²9'S e 48³9'48 $\left.36^{\prime} \mathrm{W}, \mathrm{SP}, \mathrm{Brasil}\right)$, foi determinada mensalmente a biomassa of E. polystachya com oito quadros de $0,25 \mathrm{~m}^{2}$ de agosto de 1993 a julho 1994. A variação sazonal da biomassa foi unimodal, com maior biomassa de novembro de 1993 a abril de 1994. A biomassa média determinada foi de 1.933,7 \pm 479,5 gPS.m ${ }^{-2}$, com uma variação ao longo do ano de $1.149,0$ a $2.755,9$ gPS.m $^{-2}$. A variação anual da biomassa verde aérea, detritos aquático e aéreo sugere que o principal período de crescimento de $E$. polystachya foi de dezembro de 1993 a maio de 1994, com pico entre fevereiro e março de 1994. Os dados demonstram que essa macrófita aquática está adaptada à variação do nível da água.

Palavras-chave: macrófita aquática, Echinochloa, biomassa, variação do nível da água, reservatório, Poaceae.

\section{INTRODUCTION}

Macrophytes from tropical regions grow during whole year, because there are favorable conditions of light and temperature (Shah \& Abbas, 1979; Esteves \& Camargo, 1986; François et al., 1989; Neiff, 1990; Nogueira \& Esteves, 1990; Piedade et al., 1991; Junk \& Piedade, 1993; Mos-
chini-Carlos et al., 1993; Camargo \& Esteves, 1996). In general, changes in biomass variations are due to modifications in the growth rate. The competition for light, nutrients, space etc., and the maximum growth rates don't occur simultaneously in different species coexisting in the aquatic ecosystem, and thus the peaks of biomass of different macrophytes present a lag time (Neiff, 1990). 
The water level variation is one of the more important factors associated with plant zonation as well as with the macrophytes biomass (Lieffers, 1984; Blom et al., 1990; Junk \& Piedade, 1993; Menezes et al., 1993; Camargo \& Esteves, 1996). According to Camargo \& Esteves (1995) in the aquatic environment with no significant seasonal variations of water level, biomass changes are low.

For great rivers, the highest water level occurs in general once in a year and is relatively predictable, in this case, the biota is very well adapted to water level changes (Junk et al., 1989). Some species present peaks of biomass during the flooding period (Neiff, 1975; François et al., 1989; Piedade et al., 1991). Other plants show a reduction on its biomass when they are covered by water, and they present peaks of biomass during the low water level periods (Neiff, 1975; Junk \& Piedade, 1993). Neiff (1975) also observed that modifications in vegetation composition (structure and dominance) and in biomass occur after the flooding period. Thus, the population structure after floods can be substantially modified, according to the flooding intensity. Probably, the flood duration and periodicity also produce a change in the plant composition and in the growth rates of macrophytes.

This paper aims to help the understanding of the annual biomass dynamics of an emergent macrophyte (Echinochloa polystachya (H.B.K.) Hitchcock) and its associations with water level fluctuations.

In the Amazonian rivers and lakes, E. polystachya presents great and homogeneous stands in waters rich in nutrients (Piedade et al., 1991, 1992; Piedade, 1993). Its life cycle shows two phases: one terrestrial and other one aquatic. The terrestrial phase begins with the reducing of water level and with the sediment exposure. In this period (dry phase), the biomass is low $\left(0.70 \mathrm{gDW} . \mathrm{m}^{-2}\right)$, and new shoots are produced on the nodes of the old stems. After these old stems death, new roots start to grow. In the beginning of terrestrial phase and during the initial months of aquatic phase, the plant can grow $4 \mathrm{~cm}^{-} \mathrm{day}^{-1}$, related to the water level increase. After the plant flowers the biomass can reach $8 \mathrm{kgDW} \cdot \mathrm{m}^{-2}$. After flowering, the plant continues to grow, but in a smaller rate. With the decrease of water level, the roots dry, and when sediment exposure occurs, new shoots will grow from the old stem. When there is no sediment exposure, the old stems can survive until another dry time, but the productivity of the following cycle will be lower.

\section{STUDY AREA}

In the mouth of Paranapanema River into

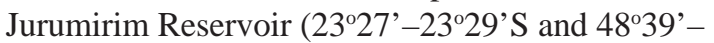
$48^{\circ} 36^{\prime} \mathrm{W}$ ), areas permanently flooded with a great extension of aquatic plants were detected. Macrophytes species observed in this zone are $E$. polystachya, Eichhornia azurea Kunth, Habenaria edwalli Conj, Scirpus cubensis Poep and Kunth, Polygonum spectabile Mart, Utricularia gibba L., Limnobium stoloniferum Griseb, Pistia stratiotis L. The grass E. polystachya is the dominant macrophyte (Fig. 1).

The rainy and dry seasons extend from October to March and from April to September, respectively. For the year extending from August 1993 to July 1994, the annual precipitation attained to $1,473.8 \mathrm{~mm}$.

In the rainy season, the suspended material concentration increased and it was observed a decrease on conductivity. A dilution effect on the conductivity was observed due to the water input from the drainage basin during the rainy season (Pompêo et al., 1997).

A slight decrease of water level, as shown by the change in the reservoir level, was observed from August to September 1993 (Fig. 2). Afterwards, because of high rainfall in middle September 1993, a fast increase of water level occurred, and a peak was found in the beginning of October 1993. Afterwards a slow decrease in water level was observed until January 1994, when the lowest level was attained. From January 1994 on, a new increase occurred which was due to the high precipitation in January 1994. This increase, linked to low water discharge, induced a water storage in the reservoir. The water level remained almost stable from $\mathrm{Fe}$ bruary 1994 to July 1994. A 2 m water level range was observed during the year and it modified the stand depth of E. polystachya. This pattern of water level variation was mainly due to the change of water discharge from the reservoir (Pompêo et al., 1997). 


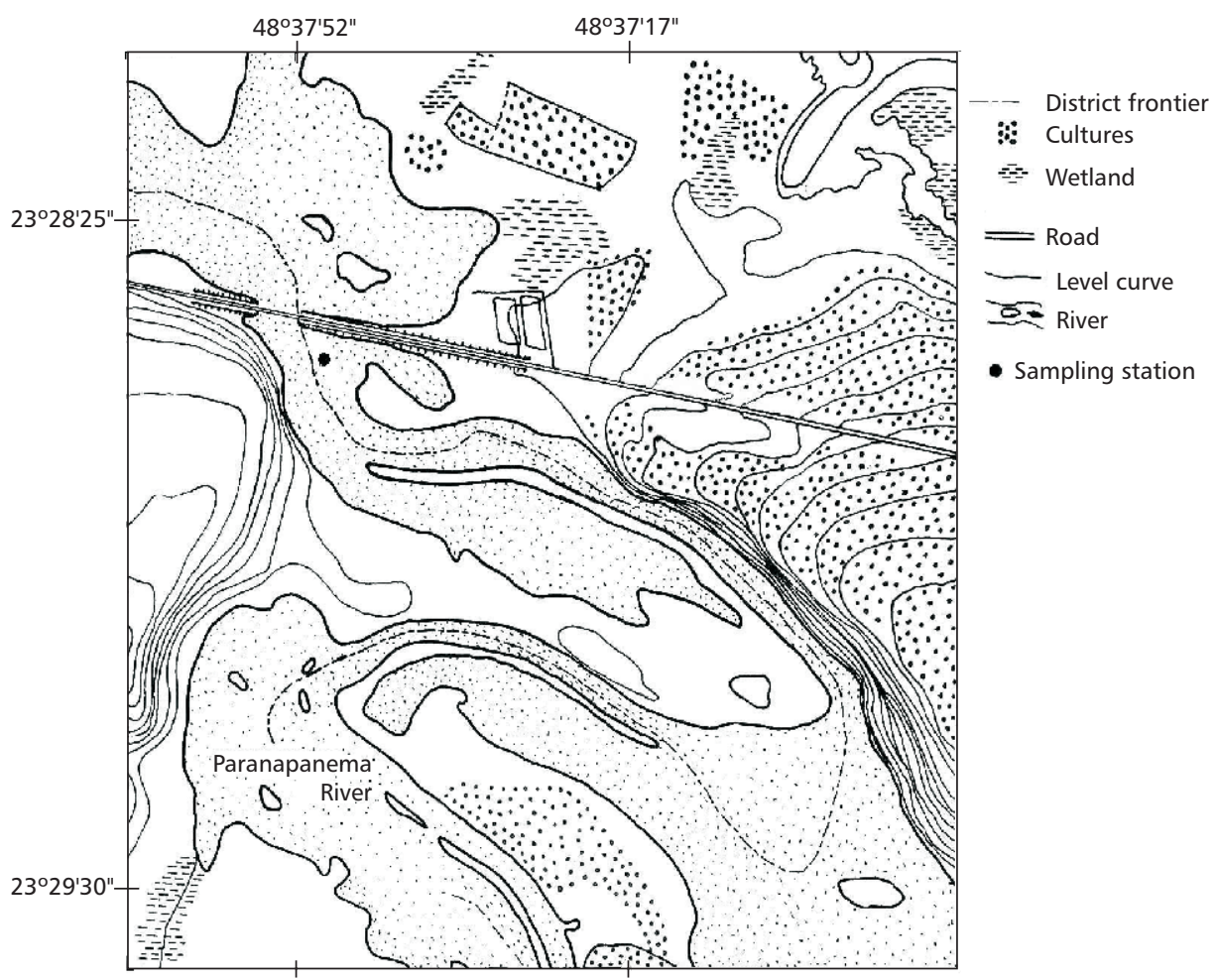

Fig. 1 - Study site (scale: 1:10,000), at mouth zone of Paranapanema River in Jurumirim Reservoir.

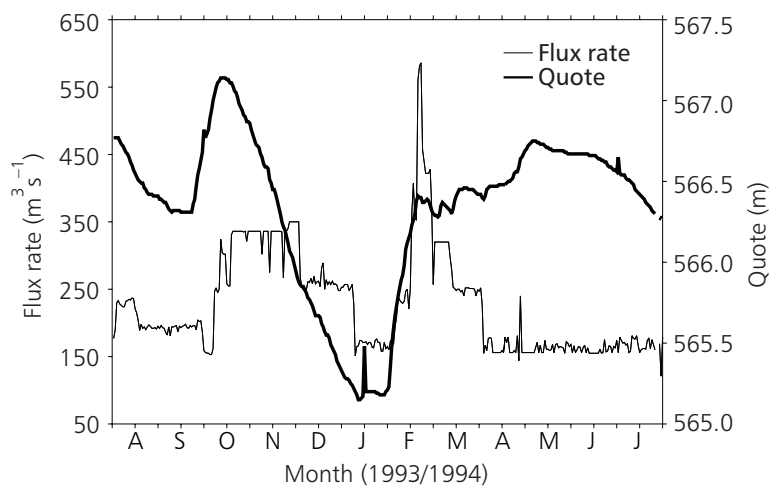

Fig. 2 - Annual water level variation $($ quote $-\mathrm{m})$ and flux rate $\left(\mathrm{m}^{3} \cdot \mathrm{s}^{-1}\right)$ of Jurumirim Reservoir.

\section{MATERIAL AND METHODS}

At the mouth of Paranapanema River, the biomass of E. polystachya from the same stand was determined monthly in two points, distant near 100 m, from August 1993 to July 1994. Plants present in four quadrats of $0.25 \mathrm{~m}^{2}$ (Westlake,
1971) were collected in each point. In the field, plants were divided in to two parts: one aerial part, the fraction above the water level, and the aquatic one, the submersed fraction (limited to $30 \mathrm{~cm}$ depth), as adopted by Nogueira \& Esteves (1990). In the laboratory, the aerial part was subdivided in green leaf blade (L.B.), a leaf blade with 
its structures less than $30 \%$ dry; the sheath (SH.); the aerial detritus (EA.D.), leaves blades and sheathes (leaf blades having more than $30 \%$ of their dry structures), and aerial stems (AE.S. - stems above the water level). The aquatic part was subdivided in aquatic stem (AQ.S.), aquatic detritus (AQ.D. - senescent vegetal material, constituted mainly by leaf blades and sheathes, and rarely by stems and roots), and roots (R.). Finally, the plant fractions were cleaned, dried $\left(65^{\circ} \mathrm{C}\right)$, cooled and weighed.

The water level was determined through ruler install inside of the stand.

\section{RESULTS}

During the year, unimodal variation of biomass was observed (Fig. 3). From November 1993 to April 1994, the biomass was higher than in the other six months. Annual average total biomass (between two points) was $1,933.7 \pm 479.5 \mathrm{gDW} \cdot \mathrm{m}^{-2}$, and ranged from $1,149.8$ to $2,755.1 \mathrm{gDW} . \mathrm{m}^{-2}$. For each point, the coefficients of variation ranged from $6.8 \%$ to $50.8 \%$. Concerning the monthly rate of two points, the coefficient ranges from $18.1 \%$ to $40.9 \%$.
The aerial and aquatic fractions of the stem include great part of the biomass (Table 1 and Fig. $4)$. The following decreasing order was detected: stems $(56.2 \%)$, aerial detritus $(13.2 \%)$, leaf blades $(12.4 \%)$, aquatic detritus $(8.2 \%)$, sheaths $(6.9 \%)$ and roots $(3.1 \%)$. During the year, in percentage, great variations on total biomass are due to the leaf blade. Aerial and aquatic stem showed the smallest variations. From February to April 1994 there was an increase in percentage of leaf blade, sheath and aquatic stem biomasses, and a decrease on the aerial detritus and aerial stem biomasses. Root biomass scarcely contributed to total biomass throughout the year. Five to eight photosynthetically active leave blades were observed on each stem above the water level. No flower of E. polystachya was seen during the study.

The variation of total green biomass (including the leaf blade, sheath, aerial and aquatic stem) showed the greatest values between December 1993 and May 1994, and a peak was observed in February 1994 (Fig. 5). The aerial green biomass (including the leaf blade, sheath and aerial stem), "peaked" between February to March 1994. From August 1993 to February 1994, the parcel of aerial detritus on total biomass was greater than aquatic detritus.

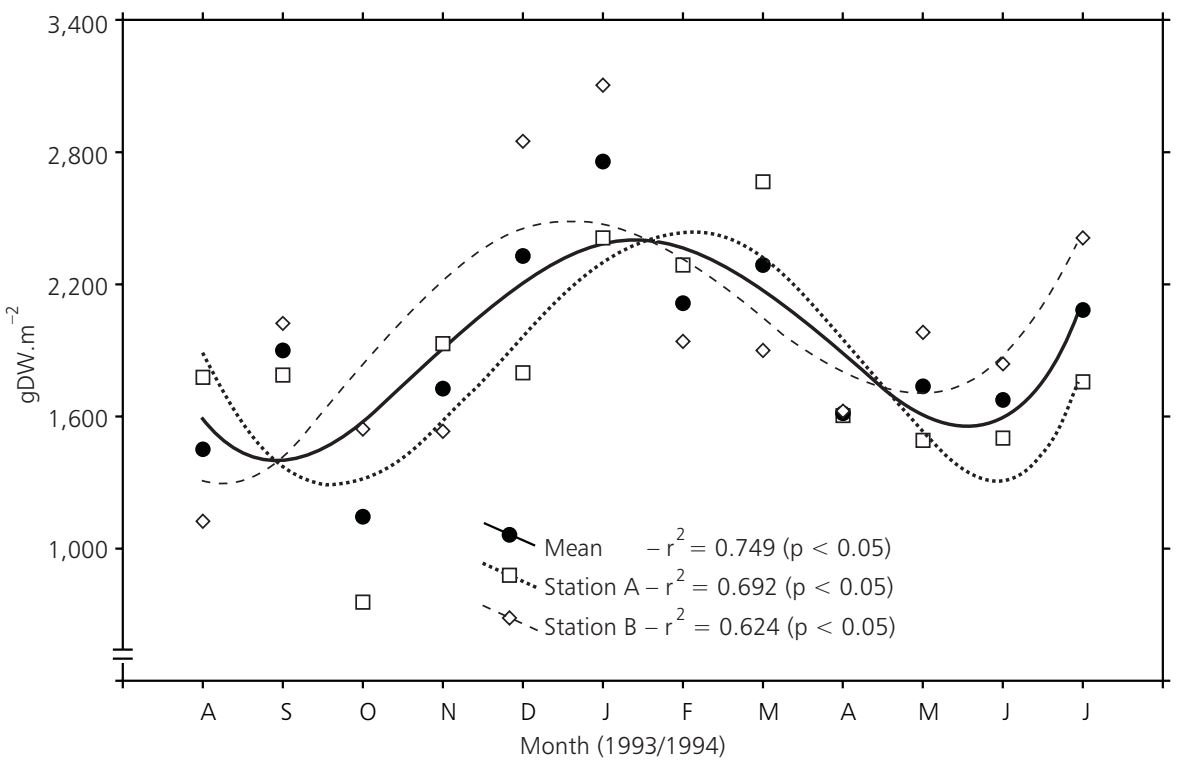

Fig. 3 - Annual variation of total biomass of E. polystachya in points A and B, and the mean value for the two points (polynomial fit: $3^{\text {rd }}$ order). 


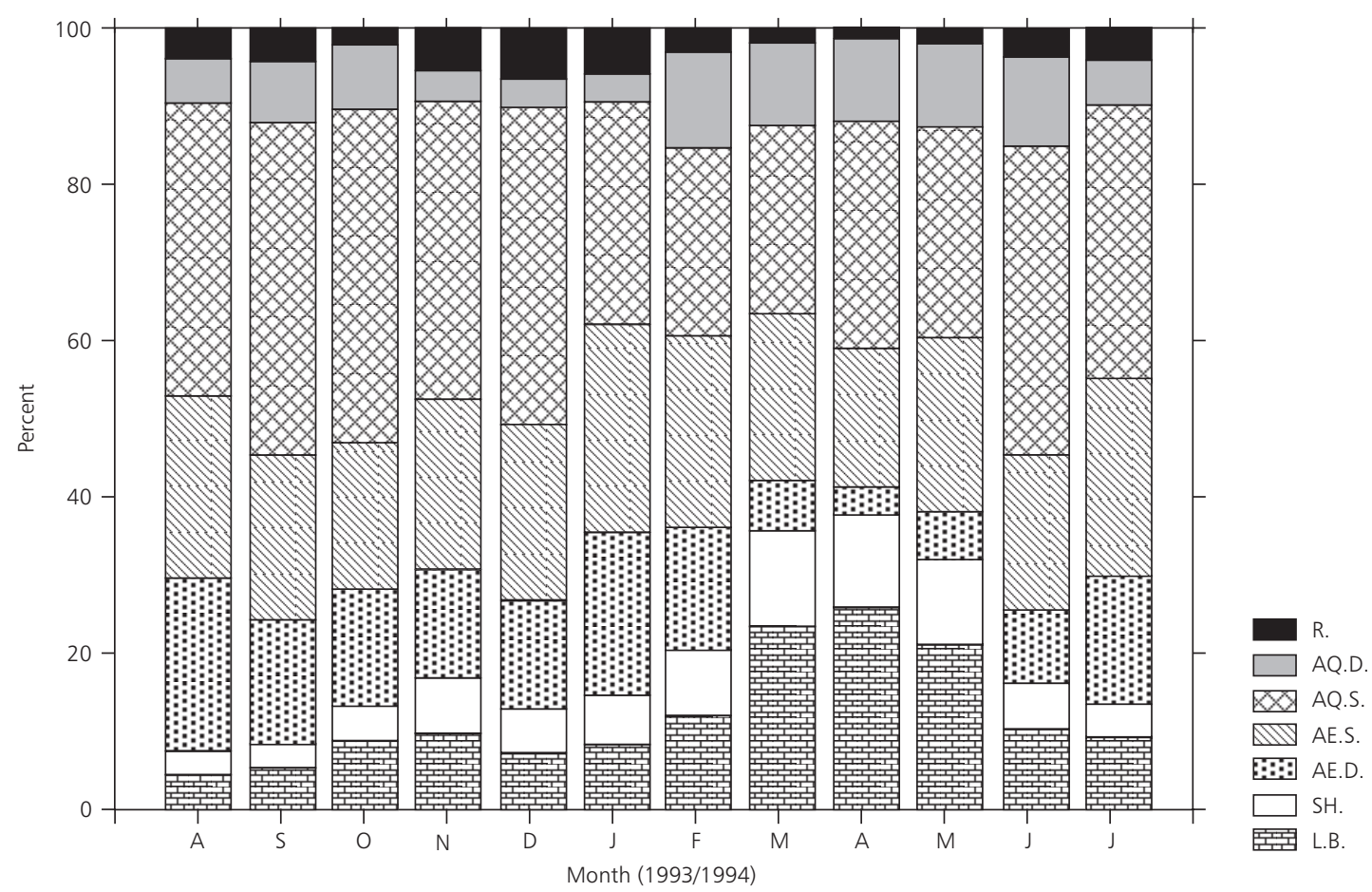

Fig. 4 - Percentages (\%) of E. polystachya fractions on total biomass.

TABLE 1

Annual percentual averages $( \pm \mathrm{sd})$ of $E$. polystachya fractions on total biomass.

\begin{tabular}{|l|c|c|c|}
\hline \multicolumn{1}{|c|}{ Fractions } & Aerial part (\%) & Aquatic part (\%) & Total biomass (\%) \\
\hline Leaf blade & $12.4 \pm 7.2$ & - & $12.4 \pm 7.2$ \\
\hline Sheath & $6.9 \pm 3.2$ & - & $6.9 \pm 3.2$ \\
\hline Detritus & $13.2 \pm 5.7$ & $8.2 \pm 3.2$ & $21.4 \pm 4.5$ \\
\hline Stem & $22.1 \pm 2.6$ & $34.1 \pm 7.1$ & $56.2 \pm 6.8$ \\
\hline Root & - & $3.1 \pm 1.6$ & $3.1 \pm 1.6$ \\
\hline Total biomass (\%) & $54.7 \pm 6.7$ & $45.6 \pm 6.6$ & 100 \\
\hline
\end{tabular}

From March to May 1994 the aquatic detritus presented greater biomass than the aerial detritus. Finally, along the rise of the water level total and aerial green and aquatic detritus increased too, and a decrease of aerial detritus biomass could be observed.

\section{DISCUSSION}

As result of water level decrease in the reservoir in January 1994, the sediment became exposed and it was observed that E. polystachya stand was rooted in the sediment. The stand showed a fluctuation according to the water-level variation, but it produced no real float cushions, as $S$. cubensis (Moschini-Carlos et al., 1993), or as the other aquatic plants in the Amazonian region (Junk, 1970). With the increase of water level in the reservoir, there was some height increase and the stand out parts were drowned.

For this reason part of the aerial biomass became aquatic. 


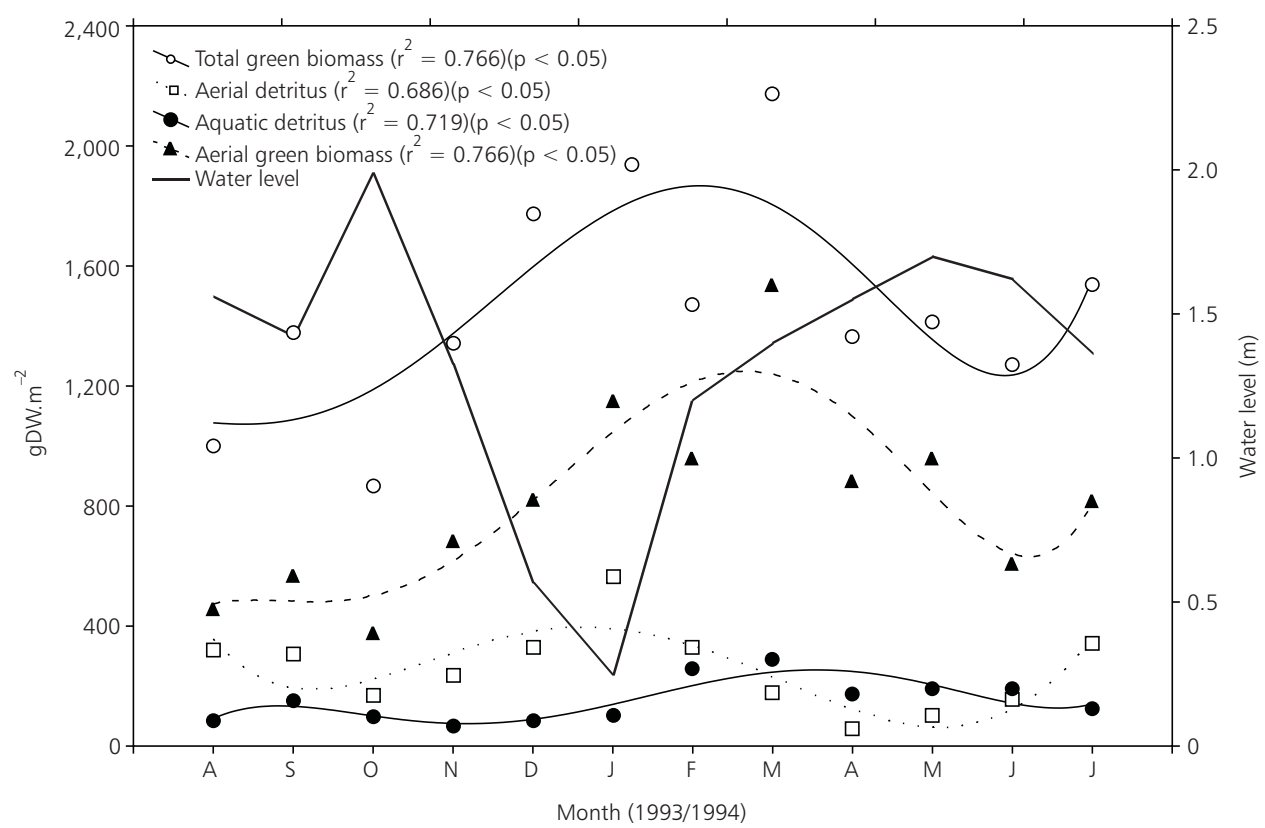

Fig. 5 - Annual variation of green total and aerial biomasses, aerial and aquatic detritus amounts of E. polystachya (mean between points - polynomial fit: $3^{\text {rd }}$ order).

An inverse situation occurred with the water level decrease when part of biomass aquatic fraction became aerial fraction again.

In the mouth of the Paranapanema River, there was an evident fluctuation on the water level, but there was no dry period (Pompêo et al., 1997), like in the Amazonian region (Piedade et al., 1991, 1992; Piedade, 1993). After the short time of sediment exposition, the stem death and the new plants growth was not observed as it happens to E. polystachya in the Amazonian region (Piedade et al., 1991, 1992; Piedade, 1993) or as to E. stagnina in Mali (François et al., 1989). Thus, a stem alone can stay alive for more than a year. Nevertheless, the annual variation of aerial green biomass showed that the main growth period of E. polystachya extended from December 1993 to May 1994, with a peak between February to March 1994. In this time, the greatest blade leaves biomass and the smallest aerial detritus biomass were observed. A high nitrogen and phosphorus contents were also detected in whole plant from January to March, with peak on February and March, respectively (Pompêo, 1996). The fast growth of stems in length, attained $2 \mathrm{~cm} \cdot$ day $^{-1}$, followed the increase of water level from January to March, as was also observed (Pompêo, 1996). The highest aquatic detritus biomass observed between March and June
1994, probably arose from the live blade leaves drowned with the water level increase.

Resources transfer patterns in E. polystachya can be compared with the seasonal variation on biomass of live compounds, detritus and roots of Eichhornia azurea Kunth in Lagoa do Mato (SP, Brazil) (Camargo \& Esteves, 1996). When the water level is high, the resources are moved to the production of live biomass, and simultaneously, a reduction on the detritus and roots biomasses is observed. This pattern is an indication of water level effect on the seasonal variation of biomass. According to Camargo \& Esteves (1996), the flood pulse produces a lake fertilization, and a modification on the biomass and chemical composition of E. azurea.

A comparison of macrophytes biomass in tropical region is presented in Table 2. The maximum biomass of $E$. stagnina is compound of aquatic stems $(71.5 \%)$, aerial stems $(18.0 \%)$, leaves $(9.5 \%)$ and inflorescence (1.0\%) (François et al., 1989).

For E. polystachya in the Amazonian region, the leaves and roots correspond to $6.5 \%$ and $4.8 \%$ of live material, respectively, and the remaining plant is constituted by stems (Piedade et al., 1991). Therefore, stems constitute the majority of biomass of these grasses, including E. polystachya from Paranapanema River. 
TABLE 2

Comparison of minimum and maximum biomass in the aquatic macrophytes from tropical regions.

\begin{tabular}{|l|c|c|c|}
\hline \multicolumn{1}{|c|}{ Aquatic macrophyte } & Sites & kgDW.m ${ }^{\mathbf{2}}$ & References \\
\hline E. stagnina & Mali & $3.0-3.2^{(1)}$ & François et al. (1989) \\
\hline E. polystachya & Manaus (Brazil) & 0.70 to 8.0 & Piedade et al. (1991) \\
\hline E. polystachya & Paranapanema River (Brazil) & 1.9 to 2.7 & this work \\
\hline Pontederia cordata L. & Lobo Reservoir (Brazil) & 0.38 to 1.82 & Menezes (1984) \\
\hline S. cubensis & Lagoa do Infernão (Brazil) & 1.3 to 2.4 & Nogueira \& Esteves (1990) \\
\hline $\begin{array}{l}\text { Eichhornia azurea } \text { Kunth } \\
\text { stem }+ \text { leaves }\end{array}$ & Lagoa do Mato (Brazil) & $0.14^{(2)}$ to $0.23^{(3)}$ & Camargo \& Esteves (1996) \\
\hline
\end{tabular}

(1) Maximum biomass; (2) May 1986; (3) March 1987.

The lowest values of the E. polystachya biomass in Jurumirim Reservoir, when compared with the biomass of this species in the Amazonian region (Table 2), may be due to the different environmental conditions. In Paranapanema River, the modifications on water level reaches $2 \mathrm{~m}$, while in the Amazonian region, the water level fluctuations are higher than $10 \mathrm{~m}$.

According to Piedade et al. (1991), the occurrence of E. polystachya in the Amazonian region is due to the high potential production of this species that presents a $\mathrm{C} 4$ metabolism, when compared with other $\mathrm{C} 3$ metabolism species. This high production is absolutely necessary for its growth and survival strategy. C3 species, despite present a high efficiency in the energy conversion, cannot grow quickly and are submersed when there is a significant increase in the water level. Mitsch \& Gosselink (1986) also reported that the adaptations of C4 plants induce selective advantage in the wetlands. The high absolute and relative growth rates in stems of E. polystachya, observed from January to March 1994 (Pompêo, 1996), when there is a very fast increase on water level, also are indications of the competitive advantages presented by $\mathrm{C} 4$ metabolism species. Thus, high productivity may also be a factor explaining the extensive distribution and dominance of E. polystachya in Jurumirim Reservoir. At Paranapanema River, primary productivity of E. polystachya was evaluated at 25 t.ha $^{-1}$.year ${ }^{-1}$ (Pompêo, 1996), which is lower than the one in Amazonian region (100 t.ha ${ }^{-1}$.year ${ }^{-1}$, according to Piedade et al. (1991).

Acknowledgments - This research was supported by Fapesp (Procs. 91/0612-5, 92/2886-8). We are grateful to H. A.
Rodrigues and M. P. F. de Oliveira for the assistance in the field and laboratory works.

\section{REFERENCES}

BLOM, C. W. P. M., BÖGEMANN, G. M., LAAN, P., VAN DER SMAN, A. J. M., VAN DE STEEG, H. M. \& VOESENEK, L. A. C. J., 1990, Adaptations to flooding in plants from river areas. Aquat. Bot., 38: 29-47.

CAMARGO, A. F. M. \& ESTEVES, F. A., 1995, Biomass and productivity of aquatic macrophytes in Brazilian lacustrine ecosystems, In: J. G. Tundisi, C. E. M. Bicudo \& T. Matsumura-Tundisi (eds.), Limnology in Brazil. ABC/SBL, Rio de Janeiro.

CAMARGO, A. F. M. \& ESTEVES, F. A., 1996, Influence of water level variation on biomass and chemical composition of the aquatic macrophyte Eichhornia azurea (Kunth) in an oxbow lake of the Rio Mogi-Guaçu (São Paulo, Brazil). Archiv Hydrobiol., 135: 423-432.

ESTEVES, F. A. \& CAMARGO, A. F. M., 1986, Sobre o papel das macrófitas aquáticas na estocagem e ciclagem de nutrientes. Acta Limnol. Brasil., 1: 273-298.

FRANÇOIS, J., RIVAS, A. \& COMPÈRE, R., 1989, Le pâturage semi-aquatique à Echinochloa stagnina (RETZ.) P.BEAUV. Étude approfondie de la plante "bourgou" et des bourgoutières situées en zone lacustre du Mali. Bull. Rech. Agron. Gemb., 24: 145-189.

JUNK, W. J., 1970, Investigations on the ecology and - biology of the "floating meadows" (Paspalo-Echinochloetum) on the middle Amazon. I. The floating vegetation and its ecology. Amazoniana, 2: 449-495.

JUNK, W. J., BAYLEY, P. B. \& SPARKS, R. E., 1989, The flood pulse concept in river-floodplain systems. In: D. P. Dodge (ed.), Proceedings of the International Large River Symposium. Can. Spec. Publi. Fish. Aquat. Sci. 106

JUNK, W. J. \& PIEDADE, M. T. F., 1993, Biomass and primary-production of herbaceous plant communities in the Amazon floodplain. Hydrobiologia, 263: 155-162. 
LIEFFERS, V. J., 1984, Emergent plant communities of oxbow lakes in north-eastern Alberta: salinity, water-level fluctuation, and succession. Can. J. Bot., 62: 310-316.

MENEZES, C. F. S., 1984, Biomassa e produção primária de três macrófitas aquáticas da represa do Lobo (Broa), $S P$. MS. Dissertation, Universidade Federal de São Carlos, São Carlos, SP, Brazil.

MENEZES, C. F. S., ESTEVES, F. A. \& ANESIO, A. M., 1993, Influência da variação artificial do nível d'água da represa do Lobo (SP) sobre a biomassa e produtividade de Nymphoides indica (L.) O. Kuntze e Pontederia cortada L. Acta Limnol. Brasil., 6: 163-172.

MITSCH, W. J. \& GOSSELINK, J. G., 1986, Wetlands. Van Nostrand Reinhold Company, New York.

MOSCHINI-CARLOS, V., SOARES, J. J. \& POMPÊO, M. L. M., 1993, Variação temporal da biomassa em uma comunidade vegetal aquática. Rev. Brasil. Biol., 53: 501509.

NEIFF, J. J., 1990, Aspects of primary productivity in the lower Paraná and Paraguay riverine system. Acta Limnol. Brasil., 3: 77-113.

NEIFF, J. J., 1975, Fluctuaciones anuales en la composition fitocenotica y biomassa de la hidrofitia en lagunas isleñas del Paraná Medio. Ecosur, 2: 153-183.

NOGUEIRA, F. M. B. \& ESTEVES, F. A., 1990, Variação temporal da biomassa de duas espécies de macrófitas aquáticas em uma lagoa marginal do rio Mogi-Guaçu (SP). Acta Limnol. Brasil., 3: 617-632.

PIEDADE, M. T. F., 1993, Biologia e ecologia de Echinochloa polystachya (H.B.K.) Hitchcock (Gramineae = Poaceae), capim semi-aquático da várzea Amazônica. Acta Limnol. Brasil., 6: 173-185.
PIEDADE, M. T. F., JUNK, W. J. \& LONG, S. P., 1991, The productivity of the $\mathrm{C} 4$ grass Echinochloa polystachya on the Amazon floodplain. Ecology, 72: 1456-1463.

PIEDADE, M. T. F., JUNK, W. J. \& DE MELLO, J. A. N., 1992, A floodplain grassland of the central Amazon. In: S. P. Long, M. B. Jones \& M. J. Roberts (eds.), Primary Productivity of Grass Ecosystems of the Tropics and Subtropics. Chapman \& Hall/Unep, London.

POMPÊO, M. L. M., 1996, Ecologia de Echinochloa polystachya (H.B.K.) Hitchcock na represa de Jurumirim (zona de desembocadura do rio Paranapanema, SP). PhD. Thesis. Universidade de São Paulo, São Carlos, SP, Brazil.

POMPÊO, M. L. M., HENRY, R., MOSCHINI-CARLOS, V. \& PADOVANI, C. R., 1997, A influência da macrófita aquática Echinochloa polystachya (H.B.K.) Hitchcock nas características físicas e químicas da água na zona de desembocadura do rio Paranapanema na represa de Jurumirim, SP. Rev. Brasil. Ecol., 1: 44-53.

SHAH, J. D. \& ABBAS, S. G., 1979, Seasonal variation in frequency, density, biomass and rate of production of some aquatic macrophytes of the River Ganges at Bhagalpur (Bihar). Trop. Ecol., 20: 127-134.

WESTLAKE, D. F., 1971, Macrophytes. In: R. A. Vollenweider (ed.), A manual of methods for measuring primary production in aquatic environments. Blackwell Scientific Publication, Oxford (I.B.P. Handbook, 12). 